Jurnal Perikanan (2020) Volume 10. No. $2: 148-157$

DOI : https://doi.org/10.29303/jp.v10i2.203

\title{
BUDIDAYA IKAN PATIN (Pangasius hypopthalmus) BERBASIS BIOFLOK DENGAN PENAMBAHAN MOLASE PADA RATIO C : N BERBEDA
}

\author{
CULTIVATION OF PATIN FISH (Pangasius hypopthalmus) \\ BASED ON BIOFLOC WITH ADDITIONSMOLAGE ON RATIO C: N DIFFERENT
}

\author{
Fujiana $^{1)}$, Dewi Nur'aeni Setyowati ${ }^{1)}$, Bagus Dwi Hari Setyono ${ }^{1)}$ \\ ${ }^{1)}$ Program Studi Budidaya Perairan, Universitas Mataram \\ *)alamat korespondensi : fujiana73@gmail.com
}

\begin{abstract}
Abstrak
Penelitian ini bertujuan untuk menganalisa budidaya ikan patin (Pangasius hypopthalmus) berbasis bioflok dengan penambahan molase pada ratio $\mathrm{C}: \mathrm{N}$ berbeda. Ikan patin yang digunakan adalah ikan patin dengan panjang rata-rata awal yaitu $6 \mathrm{~cm}$. Wadah yang digunakan adalah kontainer sebanyak 12 buah ukuran volume $40 \mathrm{~L}$ dan diisi air tawar sebanyak $35 \mathrm{~L}$ dengan padat tebar 15 ekor dalam satu wadah. Pemberian molase kedalam media budidaya ikan patin dilakukan 2 jam setelah pemberian pakan. Metode yang digunakan dalam penelitian ini menggunakan metode rancangan acak lengkap (RAL). Penelitian ini terdiri dari 4 perlakuan dengan 4 ulangan yaitu $\mathrm{P} 1=$ Kontrol (tanpa penambahan molase), $\mathrm{P} 2=$ rasio $\mathrm{C}: \mathrm{N}$ media $15, \mathrm{P} 3=$ rasio $\mathrm{C}: \mathrm{N}$ media 20 dan $\mathrm{P} 4=$ rasio $\mathrm{C}: \mathrm{N} 25$. Hasil penelitian menunjukkan bahwa budidaya ikan patin (P.hypopthalmus) berbasis bioflok dengan penambahan molase ratio $\mathrm{C}: \mathrm{N}$ berbeda tidak memberikan pengaruh yang berbeda nyata terhadap laju pertumbuhan spesifik, pertumbuhan mutlak dan kelangsungan hidup ikan patin. Namun hasil rata-rata menunjukkan bahwa perlakuan rasio C : N media 20 (P3) memberikan laju pertumbuhan spesifik,pertumbuhan mutlak dan kelangsungan hidup yang tertinggi yaitu berturut-turut 19,6gr, 2,26 gr dan 62,38\%.
\end{abstract}

Kata Kunci : Pangasius hypopthalmus, Bioflok, Molase

\begin{abstract}
This study aimed to analyze the cultivation of catfish (Pangasius hypopthalmus) based on biofloc with the addition of molasses at different $\mathrm{C}: \mathrm{N}$ ratios. The catfish used was catfish with an initial average length of $6 \mathrm{~cm}$. The container used is a container of 12 pieces with a volume of $40 \mathrm{~L}$ and filled with $35 \mathrm{~L}$ of fresh water with a stocking density of 15 birds in one container. Molasses was given to the catfish culture medium 2 hours after feeding. The method used in this study was a completely randomized design method (CRD). This study consisted of 4 treatments with 4 replications, namely P1 = Control (without addition of molasses), $\mathrm{P} 2=\mathrm{C}: \mathrm{N}$ ratio media $15, \mathrm{P} 3=\mathrm{C}: \mathrm{N}$ ratio media 20 and $\mathrm{P} 4=\mathrm{C}: \mathrm{N}$ ratio 25 . The results showed that cultivation Biofloc-based catfish (P.hypopthalmus) with the addition of different $\mathrm{C}$ : $\mathrm{N}$ molasses ratio did not have a significant effect on specific growth rate, absolute growth and survival of catfish. However, the average results showed that the treatment of $\mathrm{C}: \mathrm{N}$ ratio of media 20 (P3) gave the highest specific growth rates, absolute growth and survival, namely 19.6 gr, 2.26 gr and $62.38 \%$, respectively.
\end{abstract}

Key words: Pangasius hypopthalmus, Biofloc, Molage 
Jurnal Perikanan (2020) Volume 10. No. 2 : 148-157

DOI : https://doi.org/10.29303/jp.v10i2.203

\section{PENDAHULUAN}

Produksi ikan patin (Pangasius hypopthalmus) di Indonesia pada awalnya hanya dari hasil tangkapan namun saat ini produksinya sudah mulai dikembangkan dan ditingkatkan melalui budidaya. Pengembangan produksi untuk ikan patin (P.hypopthalmus) masih cukup besar karena memiliki potensi peluang pasar yang baik karena pada saat berukuran kecil ikan patin dapat dipelihara sebagai ikan hias dan pada saat dewasa ikan patin $(P$. hypopthalmus)sebagai ikan konsumsi. Pakan merupakan faktor utama dalam keberhasilan budidaya karena merupakan sumber energi untuk ikan. Melalui proses metabolisme pakan akan diserap oleh tubuh dan menjadi energi bagi ikan dalam reproduksi, pertumbuhan dan aktivitas lainnya (Septiana, 2017). Ikan hanya dapat memanfaatkan $25 \%$ retensi protein dalam pakan sebagai hasil produksi dan sebagian besar sisanya dibuang menjadi limbah budidaya yaitu $62 \%$ berupa bahan terlarut dan $13 \%$ menjadi partikel terendap (Suryaningrum, 2014). Produksi akhir dari pakan yang dimakan oleh ikan berupa feses sedangkan pakan yang tidak dimakan oleh ikan akan menjadi sisa pakan yang dapat berdampak dalam penurunan kualitas air dalam proses pemeliharaan ikan.

Bioflok ialah teknologi yang dapat menurunkan limbah nitrogen anorganik yang berasal dari feses dan sisa pakan (Hermawan, 2014). Teknologi bioflok dilakukan dengan menambahkan sumber karbon organik ke dalam media pemeliharaan untuk meningkatkan $\mathrm{C} / \mathrm{N}$ agar seimbang sehingga dapat merangsang pertumbuhan bakteri heterotrof yang dapat mengubah nitrogen anorganik sehingga kualitas air tetap terjaga dan menjadi biomassa bakteri yang bermanfaat sebagai pakan alami untuk meningkatkan pertumbuhan ikan (Sukardi, 2014). Penambahan $\mathrm{C} / \mathrm{N}$ merupakan penambahan perbandingan karbon organik dan nitrogen. Sumber karbon organik dibagi menjadi dua yaitu karbohidrat sederhana dan karbohidrat kompleks. Bahan baku sumber karbon organik bisa di dapatkan dari hasil produksi pertanian seperti gula, tepung tapioka, kanji, tepung terigu, molase, jagung, dedak, ampas singkong. Karbon organik yang ditambahkan akan berasosiasi dengan nitrogen membentuk mikrobial protein (Arsad, 2017). Rasio perbandingan $\mathrm{C} / \mathrm{N}$ 12-20:1 akan dapat menumbuhkan bakteri heterotrof (Mauricio, 2017).

Molase merupakan hasil samping dari proses pembuatan gula tebu (Saccharum officinarum) yang berwujud cairan kental yang diperoleh dari tahap pemisahan gula secara berulang, berwarna coklat kehitaman, dan berbentuk cairan kental. Molase mengandung 48-56\% dan sedikit mengandung unsur-unsur makro (Supriyatna, 2013). Penggunaan molase memberikan pengaruh nyata terhadap kelangsungan hidup ikan lele dumbo (Wijaya, 2014). Penggunaan molase dan tepung tapioka mampu meningkatkan produksi ikan nila sebesar 43-49 \% dibandingkan tanpa pemberian sumber karbon organik (Purnomo, 2012). Sumber karbon organik yang digunakan berasal dari hasil sampingan pengolahan gula yaitu molase. Penggunaan sumber karbon organik tersebut berdasarkan ketersediaan dan mudah didapat. Maka penelitian tentang Budidaya Ikan patin (Pangasius hypopthalmus) Berbasis bioflok dengan penambahan molase pada ratio $\mathrm{C}: \mathrm{N}$ berbeda perlu dilakukan bertujuan untuk menganalisa budidaya ikan patin (Pangasius hypopthalmus) berbasis bioflok dengan penambahan molase pada ratio $\mathrm{C}: \mathrm{N}$ berbeda.

\section{METODE PENELITIAN}

Penelitian ini dilaksanakan pada tanggal 12 Juni sampai 24 Juli 2019 Bertempat di Desa Kekeri, Dusun Gegutu Dayan Aik, Kecamatan Gunungsari.

Adapun alat - alat yang digunakan dalam penelitian ini, diantaranya: 
kontainer volume 40 liter, batu aerasi 24 biji, selang aerasi, blower, do meter, ph meter, timbangan digital, alat tulis, serokan, kamera, ember, gelas ukur ukuran 2 liter, suntikan. Dan bahan bahan yang digunakan dalam penelitian ini, diantaranya: Benih ikan patin, Molase, Probiotik aquaenzim (Bacillus, Sacharomyces, Enzim protease, Amylase, dan Cellulase), Pakan dengan kandungan protein $32 \%$.

Metode penelitian ini menggunakan rancangan acak lengkap (RAL) dengan 4 kali perlakuan dengan 3 kali ulangan. Adapun perlakuan yang digunakan sebagai berikut:

$\mathrm{P} 1=$ Kontrol (tanpa penambahan molase)

$\mathrm{P} 2=\operatorname{rasio} \mathrm{C}: \mathrm{N}$ media 15

$\mathrm{P} 3=\operatorname{rasio} \mathrm{C}: \mathrm{N}$ media 20

$\mathrm{P} 4=$ rasio $\mathrm{C}: \mathrm{N}$ media 25

Adapun sistem pengacakan yang menentukan posisi wadah menggunakan sistem lotre dengan 4 kali perlakuan dengan 3 kali ulangan sehingga didapatkan 12 unit percobaan.

\section{Analisis Data}

Data pertumbuhan dan kelangsungan hidup ikan patin dianalisis menggunakan analisis of variance (Anova) pada taraf nyata 5\%. Jika terdapat beda nyata dalam uji ANOVA maka dilakukan uji Beda Nyata Terkecil (BNT).

\section{HASIL}

Hasil pengukuran terhadap laju pertumbuhan spesifik, pertumbuhan berat mutlak, dan kelangsungan hidup ikan patin selama penelitian menunjukkan ini menunjukkan hasil yang tidak berbeda nyata pada semua perlakuan. Hasil analisis sidik ragam (Anova) terhadap laju pertumbuhan spesifik, pertumbuhan berat mutlak dan kelangsungan hidup dapat dilihat pada tabel 3 .

Tabel 3. Nilai Laju Pertumbuhan Spesifik, Pertumbuhan Berat Mutlak, dan Kelangsungan hidup ikan patin pada pemberian molase dengan rasio $\mathrm{C}: \mathrm{N}$ media berbeda.

\begin{tabular}{ccccl}
\hline \multicolumn{5}{c}{ Parameter } \\
\hline $\mathrm{N}$ & $\begin{array}{c}\text { Perlak } \\
\text { o. }\end{array}$ & $\begin{array}{c}\text { Berat } \\
\text { spesi } \\
\text { fik }\end{array}$ & $\begin{array}{c}\text { Berat } \\
\text { mutla } \\
\mathrm{k}^{\text {tn }}\end{array}$ & $\begin{array}{l}\text { Kelang } \\
\text { sungan } \\
\text { hidup }^{\text {tn }}\end{array}$ \\
\hline 1. & P1(Ko & $1,22 \pm$ & $1,16 \pm$ & $45,56 \pm$ \\
& ntrol) & 0,56 & 0,42 & 37,09 \\
2. & P2 & $1,93 \pm$ & $1,90 \pm$ & $60,00 \pm$ \\
& & 1,09 & 0,82 & 13,00 \\
3. & P3 & $1,96 \pm$ & $2,26 \pm$ & $62,38 \pm$ \\
& & 0,39 & 0,59 & 8,08 \\
4. & P4 & $1,64 \pm$ & $1,95 \pm$ & $60,33 \pm$ \\
& & 0,69 & 1,17 & 23,09 \\
\hline
\end{tabular}

Keterangan: $\quad \mathrm{P} 1=$ Kontrol (tanpa penambahan molase), $\mathrm{P} 2=$ rasio $\mathrm{C}: \mathrm{N}$ media $15, \mathrm{P} 3=$ rasio $\mathrm{C}: \mathrm{N}$ media $20, \mathrm{P} 4=$ rasio $\mathrm{C}: \mathrm{N}$ media 25

\section{Laju Pertumbuhan Spesifik}

Laju pertumbuhan spesifik adalah persentase pertambahan berat dan panjang ikan setiap harinya selama pemeliharaan yang ditunjukkan dalam satuan persen (\%). Rata-rata laju pertumbuhan spesifik ikan patin pada pemberian molase dengan rasio $\mathrm{C}$ : $\mathrm{N}$ media berbeda disajikan pada Gambar 1.

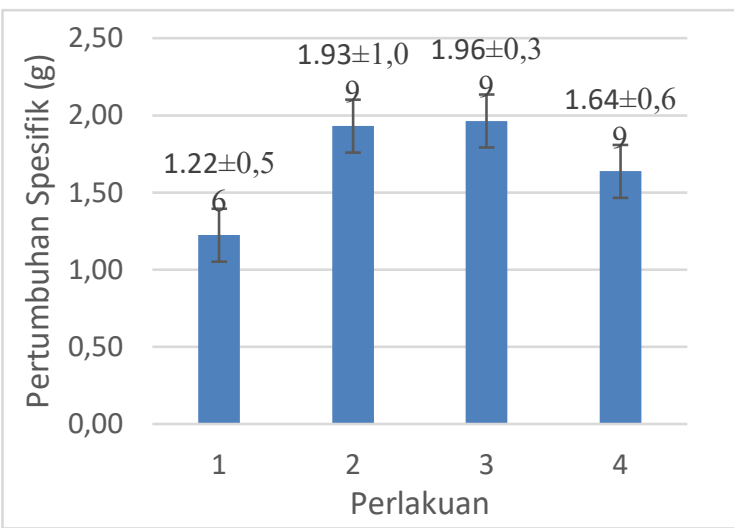

Gambar 1: Laju Pertumbuhan Spesifik Ikan Patin Pada Pemberian Molase dengan Rasio $\mathrm{C}: \mathrm{N}$ Media Berbeda

Keterangan: $\quad \mathrm{P} 1=$ kontrol (tanpa penambahan molase) $\mathrm{P} 2=$ rasio $\mathrm{C}: \mathrm{N}$ media $15, \mathrm{P} 3=$ rasio $\mathrm{C}: \mathrm{N}$ media $20, \mathrm{P} 4=$ rasio $\mathrm{C}: \mathrm{N}$ media 25 
Hasil penelitian menunjukkan bahwa perlakuan $\mathrm{P} 1=$ kontrol (tanpa penambahan molase) menghasilkan ratarata laju pertumbuhan spesifik $1,22 \pm 0,56$ g, perlakuan P2 sebesar 1,93 $\pm 1,09 \mathrm{~g}$, perlakuan P3 sebesar 1,96 $\pm 0,39 \mathrm{~g}$, dan perlakuan P4 sebesar 1,64 $\pm 0,69$ g. Setelah dilakukan analisis sidik ragam One WayAnova diperoleh hasil bahwa perlakuan pemberian molase dengan rasio $\mathrm{C}: \mathrm{N}$ media berbeda memberikan hasil yang tidak berbeda nyata $(\mathrm{P}>0.05)$ terhadap laju pertumbuhan spesifik ikan patin. Berdasarkan nilai rata-ratanya maka perlakuan pemberian molase pada rasio $\mathrm{C}$ : $\mathrm{N}$ media 20 (P3) memberikan laju pertumbuhan spesifik ikan patin yang lebih tinggi yaitu sebesar $1,96 \pm 0,39$.

\section{Pertumbuhan Mutlak}

Pertumbuhan mutlak adalah pertumbuhan yang diperoleh dari selisih berat rata-rata ikan patin pada awal pemeliharaan dengan berat rata-rata ikan patin (P.hypopthalmus) pada akhir pemeliharaan. Rata-rata laju pertumbuhan mutlak ikan patin pada pemberian molase dengan rasio $\mathrm{C}$ : $\mathrm{N}$ media berbeda disajikan pada Gambar 2.

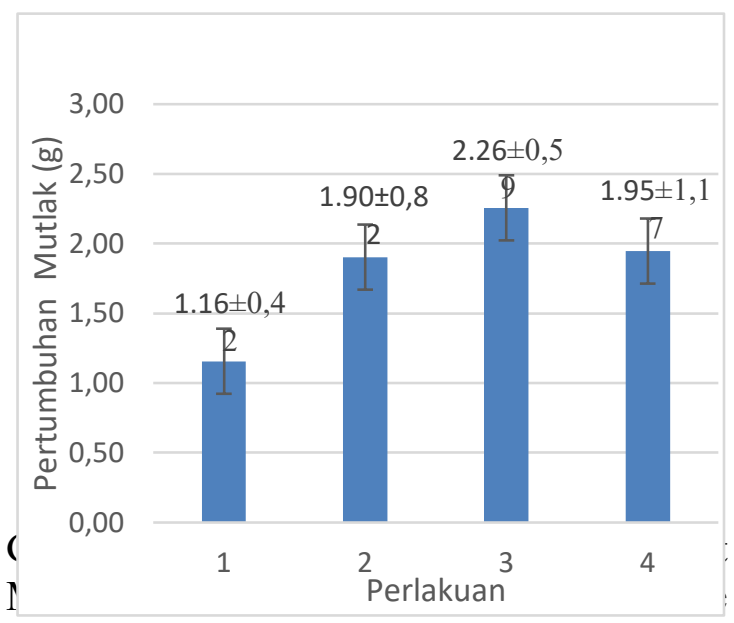

Dengan Rasio C : N Media Berbeda

Keterangan: $\mathrm{P} 1=$ Kontrol $($ tanpa penambahan molase), $\mathrm{P} 2=$ Molase media rasio $\mathrm{C}: \mathrm{N} 15, \mathrm{P} 3=$ molase media rasio $\mathrm{C}$ : $\mathrm{N} 20, \mathrm{P} 4=$ molase media rasio $\mathrm{C}: \mathrm{N} 25$
Hasil penelitian menunjukkan bahwa rata-rata pertumbuhan multak ikan patin (P.hypopthalmus) pada perlakuan $\mathrm{P} 1=$ Kontrol (tanpa penambahan molase) menghasilkan laju pertumbuhan berat mutlak sebesar 1,16 $\pm 0,42 \mathrm{~g}$, perlakuan $\mathrm{P} 2$ sebesar 1,90 $\pm 0,82 \mathrm{~g}$, perlakuan P3 sebesar $2,26 \pm 0,59 \mathrm{~g}$ dan $\mathrm{P} 4$ sebesar $1,95 \pm 1,17 \mathrm{~g}$. Setelah dilakukan analisis sidik ragam One Way-Anova diperoleh bahwa pemberian molase pada ratio $\mathrm{C}: \mathrm{N}$ berbeda memberikan hasil yang tidak berbeda nyata $(\mathrm{P}>0,05)$ terhadap laju pertumbuhan berat mutlak ikan patin (P.hypopthalmus). Berdasarkan nilai rata -ratanya maka perlakuan pemberian molase pada rasio $\mathrm{C}$ : $\mathrm{N}$ media 20 (P3) memberikan laju pertumbuhan mutlak ikan patin yang lebih tinggi, yaitu sebesar $2,26 \pm 0,59 \mathrm{~g}$.

\section{Kelangsungan hidup}

Kelangsungan hidup adalah perbandingan jumlah ikan yang hidup pada akhir pemeliharaan dengan jumlah ikan yang hidup pada awal pemeliharaan. Rata-rata tingkat kelangsungan hidup ikan patin pada pemberian molase dengan rasio $\mathrm{C}$ : $\mathrm{N}$ media berbeda disajikan pada Gambar 3 .

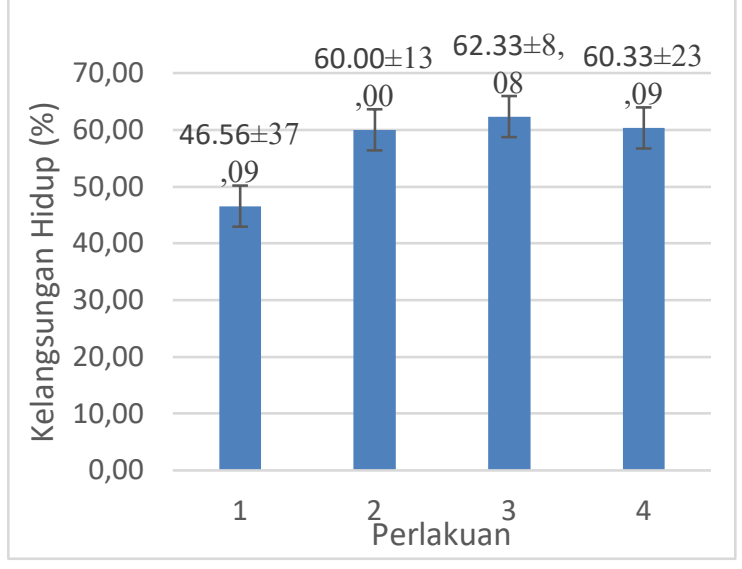

Gambar 3. Kelangsungan Hidup Ikan Patin Pada Pemberian Molase Dengan Rasio C : N Berbeda

Keterangan: $\mathrm{P} 1=$ Kontrol (tanpa penambahan molase), $\mathrm{P} 2=$ molase rasio $\mathrm{C}$ : $\mathrm{N} \mathrm{15,} \mathrm{P3=} \mathrm{molase} \mathrm{rasio} \mathrm{C}: \mathrm{N} 20, \mathrm{P} 4=$ molase rasio $\mathrm{C}: \mathrm{N} 25$ 
Hasil penelitian menunjukkan bahwa rata-rata kelangsungan hidup ikan patin ( $P$. hypopthalmus) pada perlakuan $\mathrm{P} 1=$ Kontrol (tanpa pemberian molase) sebesar 46,56 $\pm 37,09 \%$, pada perlakuan P2 sebesar $60,00 \pm 13,00 \%$, P3 sebesar $62,33 \pm 13,00 \%$ dan pada perlakuan P4 sebesar 60,33 $\pm 23,09 \%$. Setelah dilakukan analisis sidik ragam uji One Way-Anova diperoleh hasil bahwa pemberian molase media $\mathrm{C}$ : $\mathrm{N}$ berbeda menunjukkan hasil yang tidak berbeda nyata terhadap kelangsungan hidup ikan patin.
Berdasarkan nilai rata-ratanya maka perlakuan pemberian molase pada rasio $\mathrm{C}$ : $\mathrm{N}$ media 20 (P3) memberikan tingkat kelangsungan hidup ikan patin yang lebih tinggi, yaitu sebesar $62,33 \pm 13,00 \%$

\section{Kualitas Air}

Kualitas air yang diukur selama penelitian meliputi suhu, $\mathrm{pH}$ dan DO (oksigen terlarut), nitrit dan nitrat. Berikut pengukuran kualitas air pada semua perlakuan selama pemeliharaan ikan patin dapat dilihat pada Tabel. 4

Tabel.4 Hasil Pengukuran Kualitas Air

\begin{tabular}{lllll}
\hline No. & Parameter & Hasil pengamatan & \multicolumn{1}{c}{ Kisaran } & Daftar Pustaka \\
\hline 1. & Suhu & $25,4-28,3{ }^{0} \mathrm{C}$ & $25-33{ }^{0} \mathrm{C}$ & Kordi $(2010)$ \\
2. & pH & $6,6-7,4$ & $5-9$ & Rukmana $(2016)$ \\
3. & DO & $3-5 \mathrm{mg} / 1$ & $>4$ & (SNI,2000) \\
4. & Nitrit & $0,040-0,046$ & $0,05 \mathrm{mg} / 1$ & Moore $(1991)$ \\
5. & Nitrat & $2,521-2,403$ & $10-20 \mathrm{mg} / 1$ & Rakocy $(1997)$
\end{tabular}

\section{PEMBAHASAN}

\section{Pertumbuhan Spesifik}

Pertumbuhan adalah bentuk perubahan ikan dalam berat, ukuran maupun volume seiring berubahnya waktu. Laju pertumbuhan berat spesifik dihitung untuk mengetahui pertumbuhan ikan setiap hari yang dinyatakan dalam persen (Wijaya, 2016). Pada perlakuan kontrol ikan patin diberikan pakan buatan berupa pelet. Pada perlakuan yang lainnya ditambahkan sumber bahan organik berupa molase. Molase merupakan hasil samping pengolahan gula yang berbentuk cairan kental berwarna hitam. Hubungan rasio $\mathrm{C} / \mathrm{N}$ dengan mekanisme kerja bakteri yaitu bakteri memperoleh makanan melalui perbandingan substrat karbon dan nitrogen tertentu.

Hasil analisis menggunakan sidik ragam uji One-Way Anova menunjukkan bahwa pemberian molase dengan rasio $\mathrm{C}$ : $\mathrm{N}$ media berbeda semua perlakuan tidak berbeda nyata terhadap laju pertumbuhan berat spesifik harian ikan patin $(\mathrm{P}>0.05)$ sehingga pengaruh pemberian molase pada ratio $\mathrm{C}$ : $\mathrm{N}$ berbeda tidak memberikan pengaruh yang berbeda nyata terhadap laju pertumbuhan spesifik harian ikan patin. Artinya pemberian molase pada ratio $\mathrm{C}$ : $\mathrm{N}$ berbeda tidak menunjukkan tingginya pertumbuhan berat spesifik harian ikan patin (P.hypopthalmus) secara signifikan pada semua perlakuan. Hal ini diduga karena waktu pembentukan flok yang singkat sehingga mempengaruhi perkembangan flok yang mengakibatkan pembentukan flok kurang optimal. Perkembangan flok yang baik akan mempengaruhi laju pertumbuhan spesifik harian ikan patin. Menurut De schriver et al. (2008), ada beberapa faktor yang mempengaruhi pembentukan formasi dan struktur flok, salah satunya adalah sumber karbohidrat organik. Molase merupakan sumber karbon organik sederhana golongan monosakarida yang dapat dengan mudah merangsang pertumbuhan bakteri heterotrof. Suryani et al (2011) menyatakan bahwa bakteri heterotrof lebih mudah mengasimilasi monosakarida menjadi sumber energi bakteri untuk produksi sel berprotein namun flok yang 
ada di perairan tersebut mudah mati. Kemampuan bakteri untuk dapat mengurangi nitrogen anorganik dalam lingkungan budidaya dan memproduksi protein mikrobial tergantung pada koefisien konversi mikroba, $\mathrm{C} / \mathrm{N}$ rasio, biomassa mikroba, serta dari bahan karbon yang ditambahkan (Avnimelech,1999). Hasil penelitian yang dilakukan selama 45 hari menunjukkan pengaruh penambahan molase dengan dosis berbeda berbasis bioflok selama penelitian tidak berbeda nyata terhadap pertumbuhan spesifik harian ikan patin. Menurut Antony Raj et al. (2017) bahwa perbandingan $\mathrm{C} / \mathrm{N}$ rasio 20:1 atau 25:1 efektif untuk perkembangan bioflok dan mengontrol ammonia di perairan. Nilai ideal perbandingan unsur karbon dengan nitrogen untuk pembentukan bioflok 1:15 sampai 1:20 atau minimal 1:12 (Suryaningrum, 2012). Perbandingan rasio $\mathrm{C} / \mathrm{N}$ sangat penting diperlukan dalam sistem bioflok supaya bakteri hetetrotrof tumbuh dengan baik yang dapat berpengaruh dalam pembentukan flok. Peningkatan $\mathrm{C} / \mathrm{N}$ dengan rasio penambahan karbon dapat meningkatkan konversi ammonia anorganik yang bersifat toksis menjadi biomassa bakteri. Biomassa bakteri yang membentuk flok bersama-sama dengan organisme jasad renik lainnya bermanfaat sebagai sumber makanan bagi ikan. Penambahan sumber karbon mampu menumbuhkan berbagai macam bakteri pada media pemeliharaan yang diduga dapat bersaing dengan bakteri lainnya. hetetrotrof dalam bentuk bioflok, dapat dimanfaatkan oleh ikan patin sebagai pakan alami. Komunitas mikroba (bioflok) tersusun dari campuran berbagai jenis mikroorganisme (bakteri pembentuk flok, bakteri filament, fungi) partikel-partikel tersuspensi, kation, berbagai koloid, dan polimer organik, berbagai kation dan selsel mati, selain flok bakteri, berbagai jenis mikroorganisme seperti protozoa, fitoplankton dan oligochaeta.

\section{Pertumbuhan Berat Mutlak}

Pertumbuhan adalah proses bertambahnya ukuran panjang dan berat suatu organisme yang dapat diketahui dari kurun waktu tertentu. Berdasarkan hasil data selama penelitian terjadi peningkatan pertumbuhan ikan patin (P.hypopthalmus) yang ditandai dengan penambahan bobot selama penelitian. Pemberian molase pada ratio $\mathrm{C}: \mathrm{N}$ berbeda tidak memberikan pengaruh yang nyata terhadap laju pertumbuhan berat mutlak ikan patin $(\mathrm{P}>0,05)$ pada semua perlakuan. Artinya pengaruh pemberian molase pada ratio $\mathrm{C}$ : $\mathrm{N}$ berbeda tidak menunjukkan tingginya pertumbuhan berat mutlak ikan patin secara signifikan. Hal ini diduga karena pembentukan flok yang singkat sehingga mempengaruhi perkembangan bakteri heterotrof dalam pembentukan flok. Apabila penambahan sumber karbon organik eksternal yang ditambahkan seimbang dengan jumlah nitrogen dari limbah budidaya ikan patin maka jumlah bakteri heterotrof akan maksimal dan membentuk flok yang berfungsi sebagai pakan alami untuk ikan patin. Molase merupakan sumber karbon organik golongan monosakarida yang mudah dicerna oleh bakteri. Sesuai dengan pendapat Purnomo (2012) menyatakan bahwa penambahan karbohidrat seperti molase dapat merangsang pertumbuhan bakteri heterotrof. Selain bakteri, komunitas fitoplankton juga terdapat agregat bioflok seperti cyanobakteri, alga hijau, dan diatom (Schrader, et al., 2011).

Pemberian molase pada ratio $\mathrm{C}: \mathrm{N}$ berbeda tidak memberikan pengaruh yang berbeda nyata terhadap pertumbuhan berat mutlak ikan patin. Hasil ini berbanding lurus dengan pertumbuhan berat spesifik ikan patin. Rasio $\mathrm{C} / \mathrm{N}>10$ adalah rasio yang optimum untuk mengoptimalkan produksi bioflok (Hargreaves, 2006 dalam Hastuti, 2014). Umumnya rasio C/N 15 dan rasio $\mathrm{C} / \mathrm{N} 20$ lebih optimal dalam pembentukan bioflok dan mengontrol ammonia dalam budidaya. Kondisi rasio 
$\mathrm{C} / \mathrm{N}$ yang seimbang dalam media budidaya akan Bakteri heterotrof akan memanfaatkan $\mathrm{N}$, baik dalam bentuk organik maupun anorganik untuk pembentukan biomassa sehingga konsentrasi $\mathrm{N}$ dalam air akan berkurang. Perbandingan rasio $\mathrm{C} / \mathrm{N}$ sangat penting diperlukan sehingga dalam sistem bioflok bakteri dapat tumbuh dengan baik yang berpengaruh dalam pembentukan flok (Mauina, 2007 dalam Husain, 2014). Menurut Crab (2010) pada sistem bioflok ikan dapat memanfaatkan nutrisi dengan baik pada flok yang tersedia pada media pemeliharaan sehingga dapat meningkatkan pertumbuhan. Pertumbuhan juga dipengaruhi oleh beberapa faktor seperti faktor dalam dan luar. Faktor dalam adalah faktor yang disukar dikontrol yaitu seperti umur, genetik dan jenis kelamin. Sedangkan faktor luar meliputi makanan dan kuaitas air.

\section{Kelangsungan Hidup}

Kelangsungan hidup adalah perbandingan jumlah ikan yang hidup hingga akhir pemeliharaan dengan jumlah ikan pada awal pemeliharaan. Berdasarkan hasil penelitian yang dilakukan selama 45 hari bahwa pemberian molase pada ratio $\mathrm{C}$ : $\mathrm{N}$ berbeda semua perlakuan tidak memberikan pengaruh yang berbeda nyata terhadap kelangsungan hidup ikan patin $(\mathrm{P}>0.05)$. Artinya pemberian molase pada ratio $\mathrm{C}: \mathrm{N}$ berbeda tidak menunjukkan tingginya kelangsungan hidup ikan patin secara signifikan. Hal ini diduga karena pakan yang diberikan pada minggu pertama dan kedua tidak direspon oleh ikan patin sehingga menyebabkan kurangnya nutrisi yang menyebabkan ikan patin mengalami stress dan mati. Tingkat kelangsungan hidup pada ikan patin dipengaruhi oleh jenis pakan yang diberikan dan dalam jumlah benih sesuai dengan kebutuhan ikan patin. Pada kegiatan budidaya frekuensi pemberian pakan pada ikan sangat penting diperhatikan karena akan sangat berpengaruh terhadap jumlah pakan yang dikonsumsi efisiensi pakan dan kemungkinan terjadinya pengotoran lingkungan. Pengotoran lingkungan akan mempengaruhi tingkat kelangsungan hidup ikan. Pengaruh penambahan molase dengan dosis berbeda berbasis bioflok tidak memberikan pengaruh yang berbeda nyata dengan penggunaan $\mathrm{C} / \mathrm{N}$ rasio yang tinggi maka akan menyediakan sumber karbon yang mencukupi dimana bakteri akan memanfaatkan sumber karbon yang melimpah sebagai energi untuk mengasimilasi nitrogen menjadi biomassa bakteri.

\section{Kualitas Air}

Kualitas air merupakan faktor pembatas dalam pertumbuhan ikan budidaya, termasuk ikan patin. Ikan patin dapat hidup pada kualitas air yang buruk namun akan menghambat pertumbuhan karena energinya digunakan untuk bertahan pada lingkungan perairan yang buruk. Kualitas air yang diukur selama penelitian seperti suhu, $\mathrm{pH}$ dan DO (oksigen terlarut), nitrit dan nitrat menunjukkan masih dalam keadaan batas optimal untuk budidaya ikan patin.

Suhu merupakan salah satu parameter keberhasilan dalam budidaya karena sebagai pengontrol faktor yang dapat mempengaruhi kelangsungan hidup pertumbuhan ikan. Berdasarkan hasil pengukuran suhu selama penelitian diperoleh hasil berkisar antara 25,4$28,3^{\circ} \mathrm{C}$. Kisaran suhu ini merupakan kisaran yang optimal untuk kehidupan ikan patin. Menurut Kordi (2010) ikan patin hidup pada suhu berkisar $25-33^{\circ} \mathrm{C}$. Suhu yang diperoleh ini sesuai dengan kisaran suhu yang disarankan $25-30^{\circ} \mathrm{C}$. Ikan merupakan hewan berdarah dingin yang berarti suhu tubuh dipengaruhi oleh suhu lingkunganya. Peningkatan suhu dapat menyebabkan peningkatan konsumsi oksigen. Peningkatan suhu perairan sebesar $10{ }^{0} \mathrm{C}$ menyebabkan terjadinya 
peningkatan konsumsi oksigen oleh organisme akuatik sebesar 2-3 kali lipat.

Nilai $\mathrm{pH}$ menunjukkan keseimbangan asam dan basa dalam air. Nilai $\mathrm{pH}$ yang didapatkan selama penelitian berkisar 6,6-7,4. Nilai $\mathrm{pH}$ ini masih mendukung untuk pertumbuhan dan kelangsungan hidup ikan patin. Hal ini berdasarkan pernyataan Khairuman dan Sudenda (2002) bahwa ikan patin memiliki toleransi yang panjang terhadap $\mathrm{pH}$ yaitu 5,0-9,0. $\mathrm{pH}$ juga sering digunakan sebagai petunjuk derajat keasamaan suatu perairan dipengaruhi konsentarasi $\mathrm{CO}_{2}$ dan senyawa yang bersifat asam. $\mathrm{pH}$ sering digunakan untuk menentukan baik buruknya keadaan media budidaya. Benih ikan patin mempunyai toleransi yang panjang terhadap derajat keasamaan $\mathrm{pH}$ yaitu 5-9 dan optimum pada pH 7 (Rukmana, 2016).

Oksigen terlarut memegang peranan penting dalam budidaya, terutama dalam budidaya intensif yang menerapkan sistem bioflok. Jumlah oksigen terlarut yang cukup dan terus-menerus sangat dibutuhkan oleh mikroba untuk mendekomposisi bahan organik. Oksigen juga merupakan faktor pembatas dalam kegiatan pembenihan. Hal ini dikarenkan ikan dalam fase ini memiliki tingkat metabolisme dan tingkat oksigen yang tinggi. Ikan membutuhkan oksigen untuk membakar bahan bakarnya (makanan) beraktivitas, berenang, dan reproduksi. Hasil data oksigen terlarut diperoleh selama penelitian berkisar antara 3-5 mg/l,. Kisaran Oksigen terlarut yang disarankan adalah $>$ 4(SNI,2000). Menurut Minggawati dan Saptono (2012) nilai oksigen terlarut yang diperoleh sesuai yang dibutuhkan oleh ikan patin berkisar 3-7 mg/l. Nilai optimal oksigen terlarut yang sesuai berkisar 5-6 mg/l.

Nitrit merupakan bentuk peralihan antara ammonia dan nitrat (nitrifikasi) serta antara nitrat dan gas nitrogen (denitrifikasi). Nitrit adalah produk setengah jadi dari ammonia baik dalam proses nitrifikasi ammonia atau nitrifikasi nitrat. Nitrit pada perairan alami biasanya ditemukan dalam jumlah yang sangat sedikit lebih sedikit daripada nitrat karena bersifat tidak stabil diperairan. Pengujian nitrit dan nitrat dilakukan di Laboratorium Analisis Kimia, Fakultas Matematika dan Ilmu Pengetahuan Alam, Universitas Mataram. Hasil nitrit yang didapatkan pada perlakuan (P1) didapatkan nilai $0,040 \mathrm{mg} / \mathrm{l}$, pada perlakuan (P2) didapatkan nilai $0,057 \mathrm{mg} / \mathrm{l}$, pada perlakuan (P3) didapatkan nilai 0,056 $\mathrm{mg} / \mathrm{l}$, dan pada perlakuan (P4) didapatkan nilai $0,046 \mathrm{mg} / \mathrm{l}$. Moore (1991) menyatakan bahwa kadar nitrit yang melebihi nilai $0,05 \mathrm{mg} / 1$ dapat bersifat toksis bagi organisme perairan.

Nitrat merupakan hasil akhir dari proses nitrifikasi yaitu oksidasi ammonia menjadi nitrit dan oksidasi nitrit menjadi nitrat. Nitrat bersifat sangat mudah larut dalam air dan stabil serta nitrat tidak bersifat toksis bagi organisme. Hasil nitrat yang didapatkan pada perlakuan (P1) 2,521 mg/l, (P2) didapatkan nilai 3,007 $\mathrm{mg} / \mathrm{l}$, perlakuan (P3) 2,690 mg/l dan (P4) didapatkan nilai 2,403. Berdasarkan Rakocy et al (1997), menyatakan bahwa nilai nitrat yang aman dalam budidaya ikan adalah tidak melebihi 10-20 mg/l.

Konsentrasi nitrit dan nitrat menunjukkan hasil yang berlawanan. Saat nitrit rendah maka nitrat akan tinggi. Hal ini menunjukkan sedang terjadinya proses nitrifikasi. Pengujian nitrat dan nitrit hanya dilakukan pada awal pemeliharaan.

\section{KESIMPULAN}

Berdasarkan uraian pembahasan di atas, dapat disimpulkan bahwa budidaya ikan patin ( P.hypopthalmus) berbasis bioflok dengan penambahan molase pada ratio $\mathrm{C}: \mathrm{N}$ berbeda tidak memberikan pengaruh yang berbeda nyata terhadap laju pertumbuhan spesifik, pertumbuhan mutlak dan kelangsungan hidup ikan patin.Namun hasil rata-rata menunjukkan bahwa perlakuan rasio $\mathrm{C}: \mathrm{N}$ media 20 (P3) memberikan laju pertumbuhhan 
Jurnal Perikanan (2020) Volume 10. No. 2 : 148-157

DOI : https://doi.org/10.29303/jp.v10i2.203

spesifik, pertumbuhan mtlak dan kelangsungan hidup yang tertinggi,yaitu berturut-turut 1,96 gr, 2,26 gr dan 62,38 $\%$.

\section{DAFTAR PUSTAKA}

Arief, M. Fitriani N dan Subekti S. 2014. Pengaruh Pemberian Probiotik Berbeda pada Pakan Komersial terhadap Pertumbuhan dan efisiensi Pakan Ikan Lele Sakuriang (Clarias sp) Jurnal ilmiah perikanan dan Kelautan Vol. 6. No.1.

Aji. S. Bayu; S. Agung; H. Dicky; 2014. Pengaruh Penambahan Sumber Karbon Organik Berbeda terhadap Pertumbuhan dan Rasio Konversi Pakan Benih Lele "(clarias sp )" dalam Media Flok. Journal of Aquaculture Management and Technology. Vol. 3, No. 4, Halaman: 199-206.

Ananda T, Rachawati D, Samidjan I, 2015. Pengaruh Papain pada Pakan Buatan terhadap Pertumbuhan Ikan Patin (Pangasius hypopthalmus). Journal of Acuaculture Management and Technology, Vol.4. No.1. Hal:47-53.

Arsad, S. Afandy, A. Purwadhi A. P. V Betriana M. Saputra D. K. Buwono N Retno. 2017. Studi Kegiatan Budidaya Pembesaran Udang Vannamei (Litopenaeus vanname) dengan Penerapan Sistem Pemeliharaan Berbeda. 2017. Jurnal Ilmu Perikanan dan Kelautan ISSN: 2085-5842.

Emerenciano M. Gaxiola G. and. Cuzon G. 2013. Bioflock Technology (BFT) A. Review For Aquaculture Application And Animal Food Industry. Publish by: intech.

E. Mauricio Gustafo Coelho. C. Luiz Rafael Marthines , P Marcel Martinez, B Ansemol Miranda. 2017. Biofloc Technology (BFT) A Tool For Water Quality
Management in Aquaculture.Publish by: intech.

Husain N. 2014. Perbandingan Karbon dan Nitrogen pada Media Bioflok terhadap Pertumbuhan Nila Merah (Orechromis Niloticus.). Journal Rekayasa dan Technology Budidaya Perairan Vol. 3. No.1 .ISSN: 2302-3600.

Husain ,S. aya, Mohammad D.A. Ali E. A. Sallam. W.S. 2014. Journal of The Arabian Aquaculture Society Arabian Aquaculture Conference vol.9.

Imron A. Sudaryono A. 2014. Pengaruh Rasio C/N Berbeda terhadap Rasio Konversi Pakan dan Pertumbuhan Benih Lele "(clarias sp)"Dalam Media Bioflok Journal of Aquaculture Management Technology vol.3 no. 3. Hal 17-25.

Husin, M Iqbal. Suminto, dan Sudaryono A. 2017. Pengaruh Penambahan Vitamin C dan Probiotik pada Pakan terhadap Efisiensi Pemanfaatan Pakan, Pertumbuhan dan Kelulusan Hidup Ikan Patin (Pangasius hypopthalmus) Jurnal sains teknologi akuakultur 1 (2): 79-87.

Muliari, S. M , Zulfahmi I. 2017. Pengaruh Penambahan Bioflok dengan Dosis Berbeda terhadap Pertumbuhan Benih Udang Windu (Penaeus Monodon Fabricius 1798) Journal Fisherina .vol 1. No.1 ISSN: 25794051.

Lumbanbatu A Pretty.2018. Pengaruh Pemberian Probiotik Em4 dalam Pakan Buatan dengan Dosis yang Berbeda terhadap Pertumbuhan dan Kelulusan Hidup Ikan Nila Merah (Oreochromis Niloticus) Fakultas Perikanan dan Kelautan Budidaya Perairan Universitas Riau. Pekanbaru.

Notowinarto, Agustina F. 2015. Populasi Bakteri Heterotrof di Perairan Bulang Batam Journal Pendidikan 
Biologi Indonesia. Volume 1 N0 3 ISSN 2442-3750.

Rangka N Ansari dan Gunarto. Pengaruh Penumbuhan Bioflok Pada Budidaya Udang Vaname Pola Intensif Ditambak.2012. Jurnal Ilmiah Perikanan dan Kelautan.vol 4.no.2

Suhardi ,Raharjo E I, Sunarto. 2014. Tingkat Serangan Ektoparasit pada Ikan Patin (Pangasius hypopthalmus) yang Dibudidayakan dalam Karamba Sungai Kapuas Kota Pontianak. Jurnal Ruaya vol.1.no.1 ISSN:2338-1833.

Septiana A. M. Agus M. Pranggono H..2017. Pengaruh Pemberian Probiotik Dengan Dosis yang Berbeda terhadap Pertumbuhan Benih Ikan Bandeng (Chanos chanos forskal). Program Studi Budidaya Perairan Fakultas Perikanan Universitas Pekalongan Pena-Akuatika vol.15 no.1.

Sugianti Y dan Astuti L.P.2018. Respon

Oksigen Terlarut Terhadap Pencemaran dan Pengaruhnya Terhadap Keberadaan Sumber Daya Ikan Disungai Citarum. Jurnal Teknologi Lingkungan.Vol,19, N0,2

Sukardi p, Petrus $\mathrm{H}$ Tjahja Soedibya,Taufik Budhi pranomo.2014. Produksi Budidaya Ikan Nila Sistem Bioflok dengan Sumber Karbohidarat Berbeda. Asian Journal of Innovation Enterprenership E-ISN 2477-0574 P-ISN 2477-3824.

Suryaningrum F Maharani .2014.Aplikasi

Teknologi Bioflok pada

Pemeliharaan Benih Ikan Nila (Oreochromis Niloticus) Journal Manajemen Perikanan dan Kelautan.vol.1. no.1

Hermawan Teguh Eko Surya Agil Hermawan. Sudaryono A. Slamet B Prayitno 2014.Pengaruh
Pertumbuhan dan Kelulusan Benih Lele (Clarias Gariepinus) Dalam Media Bioflok Journal of Aquaculture Management and Tecnologi vol.3.no.3. hal.35-42.

Rochani A, Zuhdi Y.S. 2016. Pengaruh Konsentrasi Gula Larutan Molases Terhadap Kadar Etanol Pada Proses Fermentasi Jurnal Reka Buanan Vol.1.N0.1

Rumimpunu A, Andaki Jardie A. Manoppo E.N V. 2017. Potensi Pengembangan Usaha Budidaya Ikan Patin (Pangasius sp) Didesa Tatelu Kabupaten Minahasa Utara. Fakultas Perikanan dan Ilmu Kelautan Univeritas Sam Ratulangi, Manado.Vol.5 N0 9 ; ISSN 2337-4195

Wijaya m. Rostika R. Yuli andriani 2016. Pengaruh Pemberian $\mathrm{C} / \mathrm{N}$ Rasio Berbeda Terhadap Pembentukan Bioflok dan Pertumbuhan Ikan Lele Dumbo (Clarias garipenus) Jurnal Perikanan Kelautan vol.vii no. $141-47$

Zuhri R. 2013. Pengaruh Konsentrasi Sumber Karbon dan Nitrogen Terhadap Produksi Protease Alkali Dari Bacillus sp M1.2.3 Termofilik. Mikrobiologi Jurusan Biologi FMIPA Universitas Andalas :Padang 